\title{
INNOVATION SPECIAL ISSUE
}

\section{Innovation-oriented culture in the public sector: Do managerial autonomy and result control lead to innovation?}

\section{Public Management Review}

Jan Wynen, Koen Verhoest, Edoardo Ongaro and Sandra van Thiel ${ }^{1}$

In cooperation with the COBRA network ${ }^{2}$

\footnotetext{
${ }^{1}$ Jan Wynen is at the Public Management institute, KULeuven (jan.wynen@soc.kuleuven.be) and Koen Verhoest is at the Department of Politics (Research Group on Public Administration and Management) University of Antwerp, and affiliated with the Public Management Institute, KULeuven (Koen.verhoest@ua.ac.be). Edoardo Ongaro is at the Department of Social Sciences (Research Centre on International Public Policy and Management), Northumbria University (Edoardo.ongaro@northumbria.ac.uk) and visiting professor at Bocconi University. Sandra van Thiel is at the Institute of Management Research, Radboud University Nijmegen (s.vanthiel@ fm.ru.nl).

${ }^{2}$ The COBRA network developed a joint survey instrument to study the autonomy and control of semi-autonomous agencies. COBRA members of the following countries were involved in the collection of survey data which was used for this article: Belgium (Flanders) (Koen Verhoest, Bram Verschuere and Geert Bouckaert - University of Leuven), Italy (Edoardo Ongaro, Dario Barbieri --Bocconi University, Paolo Fedele -- Udine University; and Davide Galli -- Catholic University of Milan), The Netherlands (Sandra van Thiel -, Radboud University Nijmegen and Kutsal Yesilkagit - University of Utrecht), Hong Kong (Martin Painter - City University of Hong Kong), and Romenia (Prof. Calin Hintea and dr. Adrin Hudrea - Babes-Bolyai University). We owe many thanks to these colleagues.
} 


\begin{abstract}
This paper examines the effect of specific NPM related characteristics to explain innovation-oriented culture within public sector organizations. According to NPM doctrines, an enhanced managerial autonomy combined with result control, will stimulate a more innovationoriented culture in such organizations. Using multi-country survey data of over 200 public sector agencies, we test for the influence of organizational autonomy, result control and their interactions, on innovation-oriented culture. High levels of managerial autonomy and result control have independent and positive effects. However, the interaction between high personnel management autonomy and high result control has a negative effect.
\end{abstract}

Keywords: Innovation-oriented culture, managerial autonomy, result control, New Public Management, autonomous agencies 


\section{Organizational culture and New Public Management}

Most scholars would agree that although the heyday of New Public Management (hereafter NPM) lies behind us, it remains one of the most powerful reform doctrines to have reshaped the public sector in OECD countries and beyond. A core idea of NPM is that task specialization results in performance gains (Hood, 1991). Following this logic, governments have structurally disaggregated major public sector organizations into smaller parts, with some degree of autonomy (Laegreid and Verhoest, 2010). NPM entailed the introduction of managerial autonomy, performance management and incentives, competition and other reform elements (Dunleavy, 1996). Basically, NPM envisaged to create a stimulating environment, as much as possible similar to the private market, for senior civil servants so that they would push their organizations and staff to perform better, to take risks and to innovate (e.g. Hood, 1995; Lane, 2001; Pollitt and Bouckaert, 2011). In exchange for autonomy, public organizations (or their CEOs) would be held accountable by their minister and parliament for their performance and sanctioned or rewarded accordingly. The process by which the political principal of a public organization sets the objectives and corresponding performance targets in performance contracts, keeps the organization and its management accountable for achievement of these performance targets with respect to these standards, and, if necessary, applies sanctions to the organization or its managers will be referred to in this article as result control. It was believed that an increase in managerial autonomy combined with result control would, among others, stimulate a more innovation-oriented culture and ultimately lead to an increase of performance (see e.g. OECD 1994; 1997).

While the notion of organizational culture is well developed in the literature, it remains a highly complex phenomenon whose interconnections with other organizational dimensions, like performance, still need to find a fully-developed theoretical framing (Glick, 1985; Chia and Koh, 2007; Jenkins et al., 2008). Culture is often understood to comprise shared basic assumptions, customs, myths and ceremonies that communicate underlying beliefs about the use and distribution of power and privilege, and is evidenced by values reflected in individual and group behaviours (Pettigrew, 1979; Reigle, 2001). NPM claims that the 'right' culture is a trigger for efficiency and effectiveness (often objectives of reforms in the public sector), and that culture is a malleable component of organizations (Ongaro and Rodolfi, 1998; Schedler and Proeller, 2007). In this perspective, organizational culture is treated as an organizational feature which managers can manage and therefore change. Following this logic, managerial autonomy and result control can be determinants of organizational culture. There is however little or no empirical evidence available on this relation.

Consequently this article studies to what extent managerial autonomy combined with result control does affect the development of an organizational culture conducive to innovation. Do 
managerial autonomy and/or managerial pressures, such as result control, induce public organizations to create an innovation-oriented culture, as assumed by NPM doctrines?

In the literature there are various definitions of innovation-oriented culture. Key aspects from a cultural perspective can be described as creativity, openness, and receptiveness to new ideas, risk taking and entrepreneurial mindset (Koberg and Chusmir, 1987; Deshpandé et al., 1993; Brettel and Cleven, 2011). In short, an innovation-oriented culture encompasses both the intention to be innovative and the creation of a supportive climate for innovation (Dobni, 2008; Laegreid et al., 2011). Innovation in turn can be regarded as the adoption of an existing idea for the first time by a given organization (Damanpour, 1991; Borins, 2002; Rogers, 2003; Laegreid et al., 2011). Accordingly, innovative behavior is defined as the initiation and application of new and useful ideas, processes, products or procedures (Farr and Ford, 1990) and captures all behaviors through which employees can contribute to the innovation process.

Unfortunately, a positive correlation between managerial autonomy and organizational culture does not say much about the direction of causality; it could be that more autonomy leads to a more innovation-oriented culture, or that agencies with an innovative culture are more capable of 'extorting' a higher autonomy from oversight authorities over time (Carpenter, 2001). To solve this issue the concept of Granger causality ${ }^{3}$ can be used to test for causal relationships in both directions. This would however require longitudinal data which are not available, neither publicly nor in our dataset. We will therefore have to develop theoretical arguments about the direction of the relationship.

Furthermore, we will examine the innovation-oriented culture of a specific type of public sector organization, which we refer to as 'public sector agency'. Basically, 'agencies' are those organizations in the public sector which have higher levels of autonomy or discretion in decision making, compared to normal ministerial departments (Verhoest et al. 2012). Following Pollitt et al. (2004) and Verhoest et al. (2010) we focus specifically on public sector agencies which have the following features: 1) they are public law bodies, 2) they are structurally disaggregated from other organizations or from units within core ministries, 3) they have some capacity for autonomous decision-making with regard to management or policy, 4) they are formally under at least some control of ministers and ministries, 5) they have some expectation of continuity over time, and 6) they have some resources on their own. Companies and corporations with a commercial focus which have to closely observe the laws regulating private companies or which are registered under company law as a company as well as governmental foundations, trusts and charities are excluded from our understanding of agencies.

\footnotetext{
${ }^{3}$ The Granger causality test is a statistical hypothesis test for determining whether one time series is useful in forecasting another. See: Greene, W. (2003), "Econometric Analysis", Prentice Hall.
} 


\section{Theoretical approaches}

Research has shown that administrative reforms not only need a match with organizational culture, but also that reforms can change organizational culture (Bouckaert, 2007; Ongaro, 2009 and 2011; Laegreid et al., 2011). Basically, the NPM argument on this point boils down to two conditions that create such a culture (Kettle, 1997; Pollitt and Bouckaert, 2004; Verhoest et al., 2007). Firstly 'Let public managers manage, and hence innovate' by giving them enough managerial autonomy to develop new ways of processing and handling their business. Secondly, 'make managers innovate' by incentivizing public managers through result control by the government (OECD 1997). In general, as Osborne (1998) states: "It [the literature on innovative capacity of the public organizations and the voluntary sector] has thus been in terms of how to make them more like for-profit organizations, and consequently as more likely to be innovators" (Osborne 1998, 159). We will discuss these two lines of argument first separately and then together.

Agencification is referred not just to a process of specialisation (setting up novel organisations with narrower tasks) but to the contemporaneous process of both specialisation and autonomisation (further accompanied by the setting up of systems of steering and control, and possibly by forms of reregulation - see Pollitt and Talbot, 2004; Verhoest et al., 2004; ; Fedele et al., 2007; Verhoest et al., 2010). More precisely; we refer to agencification as the creation of semi-autonomous organizations that operate at arms' length of the government, to carry out public tasks (regulation, service delivery, policy implementation) in a relatively autonomous way i.e. there is less hierarchical and political influence on their daily operations, and they have more managerial freedoms. Autonomy is thus a constitutive component of agencification, enabling the adage of 'letting managers manage' in NPM.

More specifically, managerial autonomy is defined here as the extent to which an organization can decide independently from political and administrative principals on the choice and use of resources (Verhoest et al., 2004). The assumed beneficial effect of managerial autonomy for innovation in public sector organizations can be deduced from different theoretical angles. First, it relies strongly on the managerialist school of thought (Maor, 1999; Pollitt, 2004) which advocates the idea of "business-like government". In essence, this school expects public bureaucrats to behave like private sector managers in exploring new ways of combining production factors, provided they are given sufficient flexibility and autonomy to manage as they see fit. Under conditions of sufficient managerial autonomy and flexibility, senior civil servants will adopt an innovation-oriented behavior, leading to customer-orientation and enhanced performance (Osborne and Gaebler, 1993) - very much like private sector managers do. The attitude of senior management towards change and riskwillingness is a strong determinant for the extent of innovation in public sector and other organizations (Damanpour 1991; Rose and Shoham 2002; Shohman and Rose 2001; Vigoda-Gado 2009). 
A second related argument draws from research findings showing that in autonomous agencies political signals are attenuated and possibilities for horizontal control by peers and customers are enlarged (Egeberg, 2003; Egeberg and Trondal, 2009; Thiel and Yesilkagit, 2011). In order to retain organizational legitimacy from customers and political principals (and thus to safeguard their existence and future resources), senior agency managers will encourage the development of a customer-oriented and innovative organizational culture (see e.g. Osborne, 1998; Verhoest et al., 2007).

Another related argument looks at social identity theory which claims that in order to stimulate group identification by individuals; groups will try to emphasize their differences from other similar groups, claiming superiority by stimulating other behaviour than in the other groups. For instance, Demuzere (2012) uses this theory to explain the effect of enlarged managerial autonomy to the adoption of quality management techniques in public sector organizations, (Demuzere 2012). Following Pettigrew (1979), one could assert that the process of disaggregation from a parent administration may in fact be interpreted as a social drama, which refers to critical events whereby the opportunity to recast an organizational culture arises. In case of agencification, the newly created autonomous agencies will emphasize those features that distinguish themselves from the parent departments where they originate from (Veenswijk and Hakvoort, 2002). Van Thiel (2008) has referred to this process of differentiation between newly created agencies and their parent departments, as the human process of adolescence in which adolescents distance themselves from the values of their parents in order to shape and assert their individuality. As ministerial departments are still more infused with traditional cultures emphasizing compliance, details and precision, newly created agencies will emphasize organizational cultures which are sufficiently different: based on customerorientation, flexibility, innovation, and risk taking behavior. Indeed, van Thiel and van der Wal (2010) find that Dutch agencies with more managerial autonomy exhibit more managerial values, including innovation, than traditional departments or public sector bodies with less managerial autonomy. Lyons et al. (2006) find that work values differ between employees from core public and parapublic organizations. This is in line with findings of van der Wal (2008) whose findings indicate that managers from executive agencies and parapublic organizations with more managerial autonomy are more inclined to adopt businesslike values and also portray a desire to function more businesslike in the near future. De Bruijn and Dicke (2006) come to similar conclusions and indicate that market- like values become increasingly more important for public sector organizations that have been autonomized, liberalized or privatized. Consequently, following business-like values is expected to be valued higher in agencies than in their parent ministries (van der Wal \& Huberts 2008; Maesschalk 2004; Hood 1991, 1995) 
Some evidence does indeed seem to suggest that agencification and managerial autonomy lead to more innovation or an innovative culture (Verhoest et al. 2007). Moreover, organizational innovativeness studies emphasize the positive influence of less centralization of decision-making capacity and less formalization (Thompson, 1965; Slater and Narver, 1995; Koch and Hauknes, 2005; Vigoda-Gadot, 2009) for innovation. However, not all empirical studies show clear patterns (Damanpour, 1991; NAO, 2006; Laegreid et al., 2011).

The second 'line of argumentation' within NPM about what conditions may create or foster an innovation-oriented culture may be boiled down to the 'making managers manage' argument. Besides managerial autonomy, pressure is needed to stimulate innovation. According to NPM, such pressure can be created internally in the public sector by means of harsh performance standards in performance contracts with government, to which the agency is held accountable and to which sanctions or rewards are linked. At the delivery level, the imposition of challenging performance targets on public sector organisations and their management encourage or even force the latter to strive increased levels of efficiency and service quality, leading to a search for innovative ways to deliver services and to organise processes. Put more positively, Behn (1999) argues that goals and performance targets can redefine the meaning of success, get everyone thinking and behaving innovatively, foster leaders at all levels, and encourage organizations to reach out to other institutions whose work is helpful, or even necessary, in achieving these goals. Linking result-achievement with sanctions and rewards even increase this pressure to innovate in order to achieve high performance, because public organizations and their managers are assumed to be self-interested actors (Boorsma and Halachmi 1998; Laegreid et al 2011). Indeed, a NAO study found that efficiency goals, performance targets to improve service quality, as well as organizational performance reviews and individual performance evaluations were strong drivers for organizational innovation in the British public sector (NAO 2006). Similarly, Verhoest et al. (2007) found a positive effect of result control, including sanctions and rewards on innovation within public sector organizations in a study on state agencies. However, result control does not always directly result in higher level of innovativeness. Laegreid et al. (2011) did not find a direct effect of result control, but came to the conclusion that result control can have an indirect effect as an instrument to 'make managers manage' - i.e. as a cultural feature. Moreover, Publin researchers found that performance indicators and targets were often used in too static a way, thereby entrenching existing ways of working and inhibiting performance (Koch and Hauknes, 2005). Taking into account this nuances, we expect result control to have a positive effect on the innovation- oriented culture within public sector organizations.

In sum, NPM claims that managerial autonomy and result control are both needed in order to stimulate innovation-oriented culture and to ultimately bring about a better performance. Managerial autonomy combined with result control provides public managers with both the possibility and the 
incentive to experiment, and innovate. This allows public managers to explore more and novel options, develop and adapt new products, services and management techniques, and produce better performance (Dunleavy et al., 2006). Based on this line of reasoning, we expect managerial autonomy and result control to foster an organizational culture emphasizing innovation. In view of these mixed findings, we pose the following central question: do managerial autonomy and/or result control induce public organizations to create an innovation-oriented culture, as assumed by NPM doctrines?

The next section discusses our research design. Section 4 presents the results of our analyses and section 5 concludes this article.

\section{Methods and data}

Data used for the analysis have been provided by the "Comparative Public Organization Data Base for Research and Analysis" or COBRA-network. The COBRA network aims to encourage and enable comparative research into public sector organizations (for more information see; http://soc.kuleuven.be/io/cost/index.htm). It developed a common questionnaire in order to survey senior managers of public sector organizations. The questionnaire focuses on issues of autonomy, control and management of public sector organizations, in particular, (semi)-autonomous agencies. The joint data set comprises unique agency-level survey data spread across 15 different countries and 7 years. For this paper we will use data on agencies from five countries: Belgium (Flanders), Italy, The Netherlands, Hong Kong, Romania.

\subsection{Measuring innovation-oriented culture}

The main variable of interest, the degree to which an agency has an innovation-oriented culture, is based on an aggregation of variables which are available in the COBRA data and which specifically gauge the innovative culture of an organization. A measurement instrument for organizational culture with 36 items and nine dimensions, as developed and tested by Tepeci (2001) was used in the survey. Following Tepeci's clustering of culture-items (2001), the following set of variables is used to construct the aggregation:

- Innovation;

- risk-taking;

- willingness to experiment; and

- creativity.

Each organization was asked to indicate on a scale of 0-6 how distinctive each of these features was for their organization as a whole. These responses have been aggregated, after which they have 
been divided by 24 , resulting in a value between 0 and $1 .{ }^{4}$ The index is found to be reliable (Cronbach's Alpha is 0.8033).

\subsection{Autonomy and result control as independent variables}

Two types of managerial autonomy are taken into account; personnel management autonomy (PA) and financial management autonomy (FA). Personnel management autonomy relates to the autonomy of an agency to take decisions concerning salary level, promotion, and evaluation of staff, in general (so beyond individual decisions) without interference from ministries (see appendix, table 4, for the precise wording of these questions). For each of the three items, organizations can either have no autonomy (score 0) or full autonomy (score 1). A dummy score is calculated, based on the aggregation of the three items; whereby score 1 indicates full autonomy on all three items.

Financial managerial autonomy is measured in a similar way. An index is constructed, based on the aggregation of the scores on three items: the extent to which the organization is able to shift personnel and running cost budgets, to set tariffs for services and products, and to shift personnelrunning cost and investment budgets (cf. table 5 in the appendix). However unlike the indicators for personnel management autonomy, organizations can either have no autonomy (score 0), needing prior approval from parent ministries (score 1) or without prior approval from above (score 2). Each variable is recoded to a dummy (dummies are set to zero if score equals 0 or 1 and set to one otherwise) and then aggregated. After which this sum is again transformed to a dummy; whereby score 1 indicates full autonomy on all three items.

The measurement of result control is based on (i) the accountability of the agency CEO for agency performance (results) to the government and (ii) the extent to which the organization faces sanctions or rewards for its performance. Again a dummy variable is constructed which measures the extent to which the organization is subject to a high level of result control by government or not. A high level of result control in this case equals a 'hard' form of performance contracting, in which under- or over-performance leads to not only the accountability of the agency CEO, but also to sanctions or rewards (see Verhoest 2005; 2010). A score ' 0 ' refers to no result control or 'soft' result control (meaning CEO is accountable for the results, but without sanctions or rewards being given).

Since we expect that the effect of management autonomy is linked with result control, we construct an interaction term of high personnel management autonomy and high result control and one of high financial management autonomy and high result control. This allows us to clearly distinguish the individual and combined effects of management autonomy and result control.

\footnotetext{
${ }^{4}$ In principle the level of measurement of a Likert- type index is ordinal. However, we are treating the measurement as if it were interval. This practice allows us to create an index and it is our opinion that treating Likert- type scales as if they were interval measures provides more advantages than disadvantages in this case (7- point Likert scales).
} 


\subsection{Control variables}

In our analysis we will also control for a number of other variables, which have proven to influence innovation or organizational culture in one way or another in earlier studies (e.g. Verhoest et al. 2010; Laegreid et al. 2011).

One such variable is size (Size) in terms of number of staff, which is measured in FTE and included as a continuous variable. In organizational innovativeness studies, organizational size is said to have a negative effect, because it increases the number of communication channels, formalization and centralization and inhibits the flow of innovative ideas (Hull \& Hage 1982; Borins 2001), although Damanpour $(1989 ; 1991)$ finds a positive relation.

Another variable is budget (Budget), which is also included as continuous variable. Budget is expected to have a positive effect since large budgets allow an organization to support mechanisms for innovations in public sector organizations (e.g. Koch \& Hauknes 2005; NAO 2006; Windrum 2008; Borins 2010) although others say that financial stress encourages agencies to change routines and consequently organizational behavior. Note that Laegreid et al. (2011) do not find a relationship between budget size and innovation-oriented culture in agencies in Norway and Flanders.

Furthermore, also agencies age (Age) measured in years since founding is included as a continuous variable. According to literature (e.g. Krause 2003; Koch and Hauknes 2005) age is clearly linked to organizational culture since the development of a distinct culture and tradition within an organization takes some time (Laegreid et al. 2011).

Because the distributions of Size, Budget and Age are highly skewed, we use the logarithms, that is; $\ln$ (Size), $\ln$ (Budget) and $\ln$ (Age) in our models.

Moreover, we add dummies in order to examine the effects of agency type: a unit within government with no managerial autonomy (Type1), a unit with no legal independence but some managerial autonomy (Type2); a unit with legal independence, vested in public law (Type3); and a dummy for private law agencies (Type4). 'Unit of government without managerial autonomy (Type1)' is used as reference category and consequently omitted from the analyses. According to literature (Bouckaert and van Dooren 2003; Bach and Jann 2010) organizations closer to government are less in direct contact with citizens and are more politicized, which is typically seen as hampering managerial instruments. Likewise, organizations further away from government are more likely to develop innovation-oriented cultures.

Task related factors are also taken into account by the inclusion of a dummy (Services). The dummy equals 1 if the agency's primary task includes general public services or business and industrial services. It equals 0 for primary tasks related to regulation, exercising public authority and policy formulation. Agencies having service delivery as primary task have been found to have a 
greater focus on innovation since they interact most with citizens and private organizations as customers (Borins 1998; Vigoda-Gadot 2009; Laegreid et al. 2011).

\title{
3.4 Descriptives
}

\author{
Include Table 1
}

Table 1 shows the descriptive statistics for the dependent and explanatory variables. On average agencies in our sample employ, in number of FTE, 1460 employees and have on average been in existence for 22 years. The median budget equals 10.42 million euro's. When it comes to type, we notice that only $6 \%$ of the examined agencies report to have no legal independence but some autonomy, while $51 \%$ report to have legal independence. $12 \%$ of the examined agencies are a unit of national government and $31 \%$ is not-for-profit or private law based. From the statistics with regard to the organizational task it becomes clear that a small majority of agencies $(61 \%)$ is involved in services. In general, more agencies have high personnel management autonomy (44\%) than financial management autonomy (22\%). Furthermore only $21 \%$ of agencies report to have high result control. Finally, the average score on innovation-oriented culture equals 0.64 .

\subsection{Econometric model}

As previous sections have shown, we expect that the degree of an innovation-oriented culture $Y$ depends on personnel and financial management autonomy ( $P A \& F A)$, result control $(R C)$, other observable agency characteristics $Z$ as well as non- observable factors $\varepsilon^{5}$.

$$
Y=\beta_{0}+\beta_{1} P A+\beta_{2} F A+\beta_{3} R C+\beta_{4} P A x R C+\beta_{5} F A x R C+\sum_{k} \beta_{6} Z_{k}+\varepsilon .
$$

$\mathrm{Z}$ includes the control variables defined in previous section and a set of 4 country dummies. To estimate the relationship between the variables outlined above and $Y$ a specific econometric model is required. Ordinary least squares (OLS) is not suitable because it does not take into account that $Y$ is bounded between zero and one, which can result in impossible predictions. We use a Tobit model, where one can set the lower and upper bounds, to deal with this kind of dependent. The assumptions of homoscedasticity and normality were not violated. ${ }^{6}$ The coefficients in the Tobit model can however be interpreted in a number of ways, depending upon one's interest. We are only interested in the latent variable, following Cameron and Trivedi (2005) the marginal effect is the following:

$$
\frac{\partial E\left\{y_{i}^{*}\right\}}{\partial x_{i k}}=\beta_{k}
$$

\footnotetext{
${ }^{5}$ For simplicity, we suppress agency subscripts $i$.

${ }^{6}$ See appendix for a more detailed discussion of the model.
} 
Since agencies are nested in different countries, we have to take this country clustering into account. Failing to do so will lead to biased results. We therefore include country dummies. This way we are able to investigate relations while controlling for the influence of country characteristics.

Our analyses include interaction terms, which are difficult to interpret in non-linear models such as the Tobit model. However instead of interpreting them in terms of the probability of being censored, or the expected outcome on not being censored, we only interpret them in terms of the latent outcome. In this case the interaction terms are relatively easy to interpret. The logic is that a Tobit model is non-linear in terms of the probability of being censored or the expected outcome condition on not being censored, but is a linear model in terms of the latent variable. Consequently we can interpret the coefficient of the interaction term as we would in a linear regression.

\subsection{Robustness test: reliability of the innovation index}

There may however be a bias in the measurement of innovation-oriented culture; organizations may see themselves as innovative, but this doesn't necessarily mean that they also exhibit innovative behavior. In other words; what organizations say, should be reflected in what they do. Therefore we also include a correction of our main variable of interest for the actual use of 'new' and 'innovative' management techniques. By doing so, we are able to check the reliability of the index of innovationoriented culture. An aggregation of following set of management techniques is used as an indicator of innovative behavior ${ }^{7}$ :

- Internal allocation of resources of resources to organizational units on the basis of results;

- Internal steering of the organizational subunits and lower management levels on objectives and results;

- Assessment of results: development of internal reporting and evaluation systems to enable the governing board and the management to assess results with regard to the set objectives;

- Extension of service delivery for pay;

- Cost- calculation systems;

- Result oriented HRM (e.g., result oriented pay, setting of objectives and targets to achieve);

- Extended internal management autonomy of lower management levels concerning financial and human resources management; and

- Development of innovative products and services.

For each of these management techniques, the survey asked the agency CEO to which extent these techniques were implemented and used in their organization. These scores were aggregated and

\footnotetext{
${ }^{7}$ Cronbach's Alpha for the index of management techniques equals 0.76 .
} 
transformed to a variable with 10 categories. Apart from a score on innovation-oriented culture, each agency thus also receives a score on the use of the above mentioned management techniques, as a measurement of their innovative behavior. In order to make both scores comparable, the score on innovation-oriented culture is also transformed to a variable with 10 categories. If there is a deviation of more than 3 categories between the indexes, a penalty is given. This is only done in one way, namely when agencies have a higher score for innovation-oriented culture compared to their score for use of innovative management techniques. We thus correct for an overestimation of the value for innovation-oriented culture, or in other words for innovation-oriented culture which does not manifest itself clearly in innovative behavior at an equal level. For each difference higher than 3 categories the score of innovation-oriented culture is reduced with $10 \%$. Table 2 gives an overview of the used penalties.

Include Table 2

For example, when an agency has a very high score for innovation-oriented culture and falls within category 9 , but does not use a lot of management techniques and consequently only falls within category 1 , the initial score on innovation-oriented culture is reduced by $50 \%$.

In the following section we will discuss the results for the original and corrected index of innovation- oriented culture.

\section{Results}

The results of the Tobit estimations are presented in Table 3. Models 1 to 4 make use of the original index for innovation- oriented culture while model 5 uses the corrected index. Models 2, 4 and 5 include all explanatory variables while models 1 and 3 include only main effects of managerial autonomy and result control. Models 3, 4 and 5 include the interaction terms. When comparing models, we notice that the inclusion of extra variables has no effect on the statistical significance of autonomy- related variables. Furthermore, when comparing model 4 (original index) and model 5 (corrected index) we notice no difference in signs or significance of the independent variables, indicating that the original index of innovation- oriented culture is reliable.

High financial management autonomy proves to have a positive significant effect on the innovation-oriented culture of an agency. In other words, higher financial management autonomy will lead to a more innovation-oriented culture. High result control and high personnel management autonomy on the other hand are not statistically significant for models 1 and 2. However, these variables prove to be positive and significant for models 3, 4 and 5. These are the models that contain 
the interaction terms. The interaction term between high financial management autonomy and high result control is not statistically significant but surprisingly, the interaction term between personnel management autonomy and high result control is statistically significant but negative. The negative coefficients of the interaction term indicate that the effect of high personnel management autonomy on innovation-oriented culture decreases when it is combined with high result control (alternatively, one could say that the effect of high result control on innovation-oriented culture decreases when it is combined with high personnel management autonomy). Therefore the effect of high personnel management autonomy on the innovation-oriented culture is ambiguous, causing models without interaction terms to fail in observing the precise effect of high personnel management autonomy. This does not seem to be the case with high financial management autonomy: high result control does not alter its effect.

When examining the control variables (models 2, 4 and 5), we notice significant effects of budget and size. Larger agencies with a smaller budget will be more likely to have an innovation-oriented culture. Primary task and legal type of an agency have no statistically significant effects. Although agencies with legal independence are less likely to have an innovation-oriented culture than agencies being a unit of government (reference category), the overall effect of agency type is not significant. As mentioned previously, country dummies have been included in order to control for differences across countries. Not surprisingly, these dummies prove to be significant. In other words country specific characteristics significantly affect the innovation-oriented culture of an organization.

\section{Include Table 3}

\section{Conclusion and discussion}

The results indicate that the link between managerial autonomy and result control on the one hand and innovation-oriented culture on the other hand, is not as clear-cut as expected. High financial management autonomy, high personnel management autonomy and high result control proved each independently to have strong positive effects on innovation-oriented culture. However, when high result control is combined with high financial management autonomy, no enforcing effects were observed. On the other hand, when agencies have high personnel management autonomy while being under high levels of result control by government, they will be less likely to exhibit an innovationoriented culture. Studies analyzing the effect of reforms on change of organizational cultures have not taken the effect of the interaction between result control and managerial autonomy on organizational culture into account, which can explain the ambiguous effects of managerial autonomy and result 
control on innovative behavior and culture found in literature. This article contributes to the literature in at least three ways.

First, our conceptual set-up allows us to examine the different effects of managerial autonomy and result control, separately and in interaction, on organizational culture in detail. Furthermore by controlling for innovative behaviour, we are able to verify the reliability of the index of innovationoriented culture.

Second, the results support the assumption that granting a high level of managerial autonomy to these agencies is likely to bring about a more innovation-oriented culture in these agencies, which could be seen as a support for managerialist theories, arguments related to specialization, organizational legitimacy (Verhoest et al. 2007) or identity-building. More managerial autonomy allows for more flexibility in the use of staff and finances, more free resources for innovation and experimenting. Moreover, also 'hard' forms of result control by government, entailing performancerelated sanctions and rewards, induces higher levels of innovation-oriented organizational cultures, compared to no or 'soft' result control. Clear performance targets linked to sanctions or rewards seemingly may induce more risk-taking and experimenting (NAO 2006). However, the core of NPM, that both managerial autonomy and hard result control are simultaneously and in combination needed in order to get agencies to become more risk-willing and innovative, is not supported by our data. In case of financial management autonomy, the effect stays the same with or without result control. A possible explanation can be that agencies seldom suffer the financial consequences of their risk-taking behaviour; if sanctions are hardly ever imposed, result control becomes obsolete. Another explanation can be that if managers enjoy financial management autonomy, they will support innovative activities as indicated by our data. Yet in order to remain autonomous, they will try to increase performance by using innovative activities as a source of legitimacy or trust in the eyes to superior bodies or the general public (see Verhoest et al. 2007). This would make the use of result control in combination with financial management autonomy ineffective.

However when high personnel management autonomy is combined with high result control a lower level of innovation-oriented culture is achieved. Similarly, hard forms of result control have a positive effect but only when this is not combined with a high level of personnel management autonomy. There are two potential explanations for this. First, high personnel autonomy enables and induces managers and their staff to embark upon risky experiments, but the threat of sanctions in case of bad performance may stifle this urge to take risks. For experimenting, risk taking and innovations may fail, leading to declining performance (see Thaler et al. 1997). Hence the threat of looming sanctions may enforce risk-aversive behavior of the agency managers and their staff. A second potential explanation is the role of professionals in the (non)-diffusion of innovation (Ferlie et al. 2005). Professionals, who thrive in organizations with high levels of personnel management 
autonomy, are particularly sensitive for hard result control and related instruments, like performance targets and incentives, and may develop counteracting strategies.

A third contribution of this article lies in the lack of effects of primary task, age and type of agency, which partially refutes previous research (e.g. Borins 1998; Krause 2003; Koch and Hauknes 2005; Vigoda-Gadot 2009; Laegreid et al. 2011). For example, we found that larger agencies exhibit a stronger innovation-oriented culture, compared to smaller agencies. Apparently, the higher degree of formalization, centralization, longer communication channels and hierarchical levels which is central to large organizations does not impede innovation-orientedness. On the other hand, we found that larger budgets result in a less innovation-oriented culture - which also is in contrast with existing empirical studies. The potential consequences of failed innovations and experiments are perhaps larger in such agencies, which are known to be relatively more politically salient and hence under more scrutiny (Pollitt et al. 2004). Moreover, budgetary stress, which could be associated with smaller budgets, could enhance innovation-seeking attitudes.

Our results have some policy implications as well. Granting agencies managerial autonomy is beneficial to innovation-oriented cultures. However the use of result control will lead to ambiguous results and should therefore be well considered. Policy-makers should be aware that combining high levels of personnel management autonomy and sanctioning or rewarding them for their results (e.g. by contracts) may in fact hinder innovation. However, not only managerial autonomy and result control are important determinants of innovation- oriented culture, policy- makers should also take into account that the size of the agency's budget has an important role on the innovation- oriented culture. The higher the budget, the less likely an agency will have an innovation- oriented culture. Finally, policy- makers should be aware that an innovation- oriented culture is more likely to exist in larger organizations. When trying to encourage an innovation- oriented culture within the public sector, policy makers should thus focus on the precarious balance between managerial autonomy and result control, while taking into account the budget and size of the organization. Policy makers should thus develop different strategies for different (individual) agencies when they want to stimulate innovation since straightforward NPM recipes may be counterproductive 


\section{References}

Aucoin, P. (1990) Administrative reform in public management: paradigms, principles, paradoxes and pendulums. Governance, 3 pp115-37.

Bach, T. and Jann, W. (2010) Animals in the administrative zoo: organizational change and agency autonomy in Germany. International Review of Administrative Sciences, 76(3) (forthcoming).

Behn, R. (1999). Do Goals Help Create Innovative Organizations? In Public Management Reform and Innovation: Research,Theory, and Application, edited by H. George Frederickson and Jocelyn M. Johnston, 70-88. Tuscaloosa, AL: University of Alabama Press.

Bouckaert G. (2007) 'Cultural Characteristics from Public Management Reforms Worldwide' in K. Schedler and I. Proeller (eds). Cultural Aspects of Public Management Reforms. Amsterdam: Elsevier.

Bouckaert G. and van Dooren W. (2003) 'Performance Measurement and Management in Public Sector Organizations' in T. Bovaird and E. Löffler (eds). Public Management and Governance. London: Routledge.

Borins, S. (1998) Innovating with integrity: How local heroes are transforming American government. Washington, DC: Georgetown University Press.

Borins, S. (2001) The Challenge of Innovating in Government. The PricewaterhouseCoopers Endowment for The Business of Government, February 2001

Borins, S. (2002) Leadership and innovation in the public sector. Leadership \& Organization Development Journal, 23(8) pp467-476.

Borins, S. (2010) Strategic Planning from Robert McNamara to Gov 2.0. Public Administration Review, 70 pp220-221.

Brettel, M. and Cleven, N. J. (2011) Innovation Culture, Collaboration with External Partners and NPD Performance. Creativity and Innovation Management, 20 pp253-272.

Cameron, A.C. and Trivedi, P.K. (2005) Microeconometrics, Cambridge University Press.

Carpenter, D. P. (2001) The forging of bureaucratic autonomy: Reputations, networks, and policy innovation in executive agencies. Princeton, NJ: Princeton University Press.

Chia, Y. M., and Koh H. C. (2007) Organizational culture and the adoption of management accounting practices in the public sector: A Singapore study. Financial Accountability and Management, 23(2) pp189-213.

Damanpour, F., Szabat, K. A. and Evan, W. M. (1989) The relationship between types of innovation and organizational performance. Journal of Management Studies, 26(6) pp587-601.

Damanpour, F. (1991) Organizational innovation: A meta-analysis of effects of determinants and moderators. Academy of Management Journal, 34 pp555-590. 
de Bruijn, H. and Dicke W. (2006) Strategies for safeguarding public values in liberalized utility sectors. Public Administration, 84(3) pp717-737.

Deshpandé, R., Farley, J.U. and Webster, F.E. (1993) Corporate Culture, Customer Orientation, and Innovativeness in Japanese Firms - A Quadrad Analysis. Journal of Marketing, 57 pp23-27.

Demuzere S., (2012) Verklarende factoren van de implementatie vankwaliteitsmanagementtechnieken. Een studie binnen de Vlaamse Overheid. KUL Doctoral dissertation

Dobni C. B., (2008) Measuring innovation culture in organizations: The development of a generalized innovation culture construct using exploratory factor analysis. European Journal of Innovation Management, 11(4) pp539-559.

Dunleavy P. (1996) 'Political behaviour: Institutional and experiential approaches', in R. E. Goodin and H. D. Klingemann (eds) A New Handbook of Politics, vol. 9. Oxford: Oxford University Press.

Dunleavy, P., Margetts, H., Bastow, S. and Tinkler, J. (2006) New Public Management Is Dead Long Live Digital-Era Governance. Journal of Public Administration Research and Theory, 16(3) pp467-494.

Egeberg, M. and Trondal J. (2009) Political Leadership and Bureaucratic Autonomy. Effects of Agencification. Governance, 22(4) pp673-688.

Egeberg, M. (2003) 'How bureaucratic structure matters: An organizational perspective' in B.G.Peters and J. Pierre (eds.) Handbook of public administration. London: Sage.

Farr, J. L., \& Ford, C.M. (1990) 'Individual innovation' in M.A. West \& J.L. Farr (Eds.) Innovation and Creativity at Work. Chichester: John Wiley \& Sons.

Fedele, P., Galli, D. and E. Ongaro (2007) 'Disaggregation, autonomy and re-regulation, contractualism: public agencies in Italy (1992-2005)', Public Management Review, 9:4, pp. $557-585$.

Ferlie, E., Fitzgerald, L., Martin, W. and Hawkins, C. (2005) The non-spread of innovation: The mediating role of professionals. Academy of Management Journal, 48(1) pp117-134.

Glick, W. H. (1985) Conceptualizing and measuring organizational and psychological climate: Pitfalls in multilevel research. Academy of Management Review 10 pp601-616.

Hood, C. (1991) A Public Management for All Seasons. Public Administration 69 pp3-19.

Hood, C. (1995) Contemporary Public Management: A New Global Paradigm? Public Policy and Administration. 10(2) pp104-117.

Hull, F.M. and Hage, J. (1982) Organizing for Innovation: Beyond the Burns and Stalker's Organic Type. Sociology 16(4) pp564-577.

Jenkins, G. J., Donald, R. D., Bedard, J. C. and Curtis, M. B. (2008) Accounting firm culture and governance: A research synthesis. Behavioral Research in Accounting 20(1) pp.45-74. 
Kettle, D.F. (1997) The Global Revolution in Public Management: Driving Themes, Missing Links. Journal of Policy Analysis and Management, 16 pp446-462.

Kimberly, J. R., and Evanisko, M. J. (1981) Organizational innovation: The influence of individual, organizational, and contextual factors on hospital adoption of technological and administrative innovations. Academy of Management Journal, 24 pp689-713.

Koch, P., \& Hauknes, J. (2005) On innovation in the public sector: Academic Summary Report of Publin. Oslo: NIFU STEP, Publin Report No. D20.

Koberg, C.S. and Chusmir, L.H. (1987) Organizational Culture Relationships with Creativity and other Job-Related Variables. Journal of Business Research, 15 pp397-409.

Krause, G. A. (2003) 'Agency risk propensities involving the demand for bureaucratic discretion' in G.A. Krause and K. J. Meier (Eds.) Politics, policy and organizations: Frontiers in the scientific study of bureaucracy. Ann Arbor, MI: University of Michigan Press.

Lane, J.E. (2001) New Public Management. London: Routledge.

Laegreid, P., \& Verhoest, K. (Eds.) (2010) Governance of public sector organizations. Basingstoke: Palgrave Macmillan

Laegreid, P., Roness P. G., Verhoest, K. (2011) Explaining the Innovative Culture and Activities of State Agencies. Organization Studies, 32(10) pp1321-1347.

Lyons, S. T., L. E. Duxbury, et al. (2006) A Comparison of the Values and Commitment of Private Sector, Public Sector, and Parapublic Sector Employees. Public Administration Review 66(4): 605-618.

Maesschalck, J. (2004) The impact of New Public Management reforms on public servants' ethics: towards a theory. Public Administration. 82 (2) pp465-489.

Maor, M. (1999) The paradox of managerialism. Public Administration Review, 59 pp5-18.

NAO (2006) Achieving innovation in central government organisations: Detailed research findings. London: National Audit Office HC 1447-II, Session 2005-2006.

OECD (1994) Performance Management in Government: Performance Measurement and Results Oriented Management (Paris: Public Management Committee, OECD)

OECD (1997) In Search of Results: Performance Management Practices in Ten OECD Countries (Paris: Public Management Committee, OECD)

Ongaro, E. (2009) Public Mangement Reform and Modernization: Trajectories of Administrative Change in Italy, France, Greece, Portugal and Spain. Cheltenham, UK and Northampton, MA: Edward Elgar.

Ongaro, E. (2011) "The role of politics and institutions in the Italian administrative reform trajectory”, Public Administration, Vol. 89, No. 3 (738-755). 
Ongaro, E. and E. Rodolfi (1998) "L'innovazione nella gestione delle università italiane: uno studio di casi di introduzione del controllo di gestione" [Innovation in the management of Italian universities: a multiple case study of introduction of the management control system, Azienda Pubblica, No. 1-2 (77-101).

Osborne, S. (1998) Voluntary Organizations and Innovation in Public Services. London and New York: Routledge.

Osborne, D. and Gaebler T.(1993) Reinventing Government: How the Entrepreneurial Spirit is Transforming the Public Sector. New York: Penguin.

Papke, L. E, Wooldridge J. M. (1996) Econometric methods for fractional response variables with an application to 401(k) plan participation rates. Journal of Applied Econometrics, 11 pp619-632.

Pettigrew A. M. (1979) On Studying Organizational Cultures. Administrative Science Quarterly, 24(4) pp570-581.

Pollitt, C. and Bouckaert G. (2004) Public management reform: A comparative analysis.2d ed. Oxford: Oxford University Press.

Pollitt, C. (2004) 'Theoretical overview' in C. Pollitt and C. Talbot (eds): Unbundled Government. A critical analysis of the global trend to agencies, quangos and contractualisation. London: Routledge.

Pollitt, C. and Bouckaert, G. (2011) Public management reform: a comparative analysis - NPM, New Public Governance and the Neo-Weberian State ( $3^{\text {rd }}$ edition), Oxford, Oxford University Press.

Pollitt, C., Talbot, C., Caulfield, J., and Smullen, A. (2004) Agencies. How Government Do Things With Semi-autonomous Organizations. Basingstoke: Palgrave Macmillan.

Reigle, R. F. (2001) Measuring organic and mechanic cultures. Engineering Management Journal, 13 (4) $\mathrm{pp} 3-8$.

Rogers, E. M. (2003) Diffusion of innovations (5th ed.). New York: Free Press.

Schedler, K. and I. Proeller, Eds. (2007) Cultural Aspects of Public Management Reform. Oxford, UK, Elsevier.

Slater, S. and Narver, J. (1995) Market orientation and the learning organisation, Journal of Marketing, 59(3) pp63-74.

Talbot, C. (2004) 'The Agency Idea' in C. Pollitt and C. Talbot (eds) Unbundled Government London: Routledge.

Thaler, R., Tversky, A., Kahneman, D., Schwarz, A. (1997) The effect of myopia and loss aversion on risk taking: an experimental test. Quarterly Journal of Economics, 112 pp647661.

Thompson, V.A. (1965) Bureaucracy and innovation. Administrative Science Quarterly, 10 pp1-20. 
Tepeci, M. (2001) The effect of personal values, organizational cultures, and person-organization fit on individual outcomes in the restaurant industry. University Park, PA: Pennsylvania State University, School of Hotel, Restaurant and Recreation Management, doctoral dissertation.

Thiel, S. van (2008). Het lege nest syndroom: ministeries na verzelfstandiging. In: F. Ankersmit \& L.Klinkers. (red.). De tien plagen van de staat: de bedrijfsmatige overheid gewogen. Amsterdam, Van Gennep. [pp.170-188]

Thiel, S. van \& Z. van der Wal. (2010). The effect of organizational value congruence on the relationship between ministries and quangos. Public Organization Review, 10 pp377-397

Thiel, S. van and Yesilkagit K. (2011) Good Neighbours or Distant Friends? Trust between Dutch Ministries and their Executive Agencies Public Management Review, 13(6) pp783-802.

Veenswijk, M., \& Hakvoort, J. L. M. (2002) Public-private transformations. Institutional shifts, cultural changes and altering identities: two case studies. Public Administration, 80 (3) pp543 -555 .

Verhoest, K., Peters, B.G., Bouckaert G. and Verschuere B. (2004) The study of organisational autonomy: a conceptual review. Public Administration and Development, 24(2) pp 101-18.

Verhoest, K., Verschuere B. and Bouckaert G. (2007) Pressure, Legitimacy, and Innovative Behavior by Public Organizations. Governance, 20 (3)pp 469-497.

Verhoest, K., Roness, P. G., Verschuere, B., Rubecksen, K., and MacCarthaig, M. (2010) Autonomy and control of state agencies: comparing states and agencies. Hampshire: Palgrave Macmillan.

Verhoest K., van Thiel S., Bouckaert G. \& Lægreid P. (Eds.) 2012. Government Agencies in Europe and Beyond: Practices and Lessons from 30 Countries. Basingstoke: Palgrave Macmillan.

Verhoest, K. (2005) Effects of autonomy, performance contracting, and competition on the performance of a public agency : a case study. Policy Studies Journal, 33(2)pp 235-258.

Vigoda-Gadot, E. (2009) Building strong nations: Improving governability and public management. Aldershot: Ashgate.

Wal, Z. van der \& L.W.J.C. Huberts (2008). Value Solidity in Government and Business. Results of an Empirical Study on Public and Private Sector Organizational Values. American Review of Public Administration 38 (3): 264-285.

Windrum, P. (2008) 'Innovation and entrepreneurship in public services' in P. Windrum and P. Koch (Eds) Innovation in public sector services: Entrepreneurship, creativity and management. Cheltenham: Edward Elgar.

Wooldridge, J. M. (2002) Econometric Analysis of Cross Section and Panel Data. Cambridge, MA: MIT Press. 


\section{Tables and figures}

Table 1 Summary statistics

\begin{tabular}{llrrr}
\hline \hline Variable & Description & Mean & Std.Dev. & Median \\
\hline $\begin{array}{l}\text { Dependent variables } \\
\text { Innovation-oriented culture }\end{array}$ & Proportion & 0,64 & 0,19 & 0,67 \\
Independent variables & & & & \\
High pers. man. aut. & Dummy & 0,44 & 0,50 & 0,00 \\
High fin. man. aut. & Dummy & 0,22 & 0,42 & 0,00 \\
High res. contr. & Dummy & 0,21 & 0,41 & 0,00 \\
Primary task & & & \\
$\quad$ Services & Dummy & 0,61 & 0,49 & 1,00 \\
Age $\quad$ Continuous & 22,05 & 28,83 & 12,00 \\
Type $\quad$ Unit of national government (ref.cat.) & & & \\
$\quad$ No legal independence but some autonomy & Dummy & 0,12 & 0,32 & 0,00 \\
$\quad$ Legal independence & Dummy & 0,06 & 0,24 & 0,00 \\
$\quad$ not- for- profit or private law based & Dummy & 0,51 & 0,50 & 1,00 \\
Budget (million $€$ ) & Dummy & 0,31 & 0,47 & 0,00 \\
Size (FTE) & Continuous & 1564,97 & 15056,46 & 10,42 \\
\hline
\end{tabular}

$\mathrm{N}=222$. All variables are available for the following countries: Belgium ( $81 \mathrm{obs}$.$) , Italy ( 24 \mathrm{obs}$.), the Netherlands ( 54 obs.), Hong Kong (33 obs.) and Romania (30 obs.). 
Table 2 Used penalties

Innovation-oriented culture

\begin{tabular}{|c|c|c|c|c|c|c|}
\hline 10 & 9 & 8 & 7 & 6 & 5 & \\
\hline$-10 \%$ & & & & & & 6 \\
\hline$-20 \%$ & $-10 \%$ & & & & & 5 \\
\hline$-30 \%$ & $-20 \%$ & $-10 \%$ & & & & 4 \\
\hline$-40 \%$ & $-30 \%$ & $-20 \%$ & $-10 \%$ & & & 3 \\
\hline$-50 \%$ & $-40 \%$ & $-30 \%$ & $-20 \%$ & $-10 \%$ & & 2 \\
\hline$-60 \%$ & $-50 \%$ & $-40 \%$ & $-30 \%$ & $-20 \%$ & $-10 \%$ & 1 \\
\hline
\end{tabular}


Table 3 Tobit estimations

\begin{tabular}{|c|c|c|c|c|c|}
\hline & \multicolumn{4}{|c|}{ Original Index } & \multirow{2}{*}{$\begin{array}{c}\begin{array}{c}\text { Corrected } \\
\text { index }\end{array} \\
\text { Model } 5 \\
\mathrm{dF} / \mathrm{dx}\end{array}$} \\
\hline VARIABLES & $\begin{array}{c}\text { Model } 1 \\
\mathrm{dF} / \mathrm{dx}\end{array}$ & $\begin{array}{c}\text { Model } 2 \\
\mathrm{dF} / \mathrm{dx}\end{array}$ & $\begin{array}{c}\text { Model } 3 \\
\mathrm{dF} / \mathrm{dx}\end{array}$ & $\begin{array}{c}\text { Model } 4 \\
\mathrm{dF} / \mathrm{dx}\end{array}$ & \\
\hline High pers. Man. Aut. (1) & $\begin{array}{c}0.029 \\
(0.030)\end{array}$ & $\begin{array}{c}0.047 \\
(0.032)\end{array}$ & $\begin{array}{l}0.071 * \\
(0.037)\end{array}$ & $\begin{array}{c}0.095 * * \\
(0.038)\end{array}$ & $\begin{array}{c}0.103 * * * \\
(0.037)\end{array}$ \\
\hline High fin. Man. Aut. (2) & $\begin{array}{c}0.114 * * * \\
(0.032)\end{array}$ & $\begin{array}{c}0.103 * * * \\
(0.036)\end{array}$ & $\begin{array}{c}0.114 * * * \\
(0.037)\end{array}$ & $\begin{array}{c}0.101 * * * \\
(0.039)\end{array}$ & $\begin{array}{c}0.086 * * \\
(0.037)\end{array}$ \\
\hline High res. Con. (3) & $\begin{array}{c}0.033 \\
(0.028)\end{array}$ & $\begin{array}{c}0.036 \\
(0.028)\end{array}$ & $\begin{array}{c}0.083 * * \\
(0.036)\end{array}$ & $\begin{array}{c}0.093 * * \\
(0.036)\end{array}$ & $\begin{array}{c}0.120 * * * \\
(0.035)\end{array}$ \\
\hline Interaction (1) \& (3) & & & $\begin{array}{c}-0.113 * * \\
(0.054)\end{array}$ & $\begin{array}{c}-0.125^{* *} \\
(0.053)\end{array}$ & $\begin{array}{c}-0.140 * * * \\
(0.051)\end{array}$ \\
\hline Interaction (2) \& (3) & & & $\begin{array}{l}-0.020 \\
(0.071)\end{array}$ & $\begin{array}{l}-0.016 \\
(0.070)\end{array}$ & $\begin{array}{l}-0.039 \\
(0.068)\end{array}$ \\
\hline Services & & $\begin{array}{c}0.030 \\
(0.030)\end{array}$ & & $\begin{array}{c}0.028 \\
(0.030)\end{array}$ & $\begin{array}{c}0.037 \\
(0.029)\end{array}$ \\
\hline Age & & $\begin{array}{l}-0.023 \\
(0.015)\end{array}$ & & $\begin{array}{l}-0.024 \\
(0.015)\end{array}$ & $\begin{array}{l}-0.018 \\
(0.014)\end{array}$ \\
\hline Type2 & & $\begin{array}{c}0.002 \\
(0.063)\end{array}$ & & $\begin{array}{l}-0.013 \\
(0.062)\end{array}$ & $\begin{array}{l}-0.009 \\
(0.060)\end{array}$ \\
\hline Type3 & & $\begin{array}{c}-0.076^{*} \\
(0.044)\end{array}$ & & $\begin{array}{c}-0.093^{* *} \\
(0.044)\end{array}$ & $\begin{array}{c}-0.088 * * \\
(0.043)\end{array}$ \\
\hline Type4 & & $\begin{array}{l}-0.061 \\
(0.053)\end{array}$ & & $\begin{array}{l}-0.071 \\
(0.053)\end{array}$ & $\begin{array}{l}-0.053 \\
(0.051)\end{array}$ \\
\hline Budget & & $\begin{array}{c}-0.017 * * \\
(0.007)\end{array}$ & & $\begin{array}{c}-0.016 * * \\
(0.007)\end{array}$ & $\begin{array}{c}-0.014 * * \\
(0.007)\end{array}$ \\
\hline Size & & $\begin{array}{c}0.018^{* *} \\
(0.008)\end{array}$ & & $\begin{array}{l}0.016^{*} \\
(0.008)\end{array}$ & $\begin{array}{c}0.019 * * \\
(0.008)\end{array}$ \\
\hline Country dummies & Included & Included & Included & Included & Included \\
\hline Observations & 222 & 222 & 222 & 222 & 222 \\
\hline Log- Likelihood & 57.680 & 65.282 & 60.222 & 68.371 & 75.368 \\
\hline $\begin{array}{l}\text { McKelvey \& Zavoina's R2: R } \\
\text { Joint significance of country } \\
\text { dummies }\end{array}$ & $\begin{array}{c}0.104 \\
3.26 * *\end{array}$ & $\begin{array}{c}0.124 \\
3.92 * * *\end{array}$ & $\begin{array}{c}0.124 \\
3.38 * *\end{array}$ & $\begin{array}{c}0.186 \\
4.41 * * *\end{array}$ & $\begin{array}{c}0.200 \\
3.41 * *\end{array}$ \\
\hline Joint significance of type dummies & - & 1.33 & - & 1.80 & 1.81 \\
\hline
\end{tabular}




\section{Appendix}

\section{Table 4 survey questions used for construction of indexes on managerial autonomy}

\begin{tabular}{|c|c|}
\hline 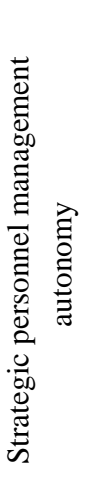 & $\begin{array}{l}\text { Provided that the organization has own staff, can the organization without interference from above } \\
\text { (without ministerial or departmental influence) set the general policy for the organization conditions } \\
\text { for promotions? } \\
\text { Provided that the organization has own staff, can the organization without interference from above } \\
\text { (without ministerial or departmental influence) set general policy for the level of salaries? } \\
\text { Provided that the organization has own staff, can the organization without interference from above } \\
\text { (without ministerial or departmental influence) set general policy for the way of evaluating } \\
\text { personnel? }\end{array}$ \\
\hline 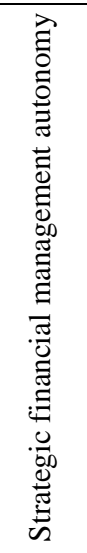 & $\begin{array}{l}\text { Can your organization itself shift between the budgets for personnel- running costs without } \\
\text { approval from above (ministerial or departmental approval)? } \\
\text { Can your organization itself set tariffs for services or products without approval from above } \\
\text { (ministerial or departmental approval)? } \\
\text { Can your organization itself shift between the budgets for personnel or running costs on the one } \\
\text { hand and investments on the other hand without approval from above (ministerial or departmental } \\
\text { approval)? }\end{array}$ \\
\hline
\end{tabular}




\section{Econometric Estimates}

The estimated Tobit model can be written as follows (see e.g. Greene 2000):

$$
Y_{i}^{*}=X_{i}^{\prime} \beta+\varepsilon_{i} \text {, with } \varepsilon_{i} \sim \mathrm{N}\left(0, \sigma^{2}\right)
$$

Where $Y^{*}$ stands either for innovation- oriented culture or the corrected index of innovationoriented culture. $X$ represents a matrix of regeressors, $\beta$ are the parameters which have to be estimated and $\varepsilon$ is the disturbance term.

We have to take some assumptions underlying the Tobit model into account such as normal distributed errors and homoscedasticity, so $\varepsilon \sim \mathrm{N} 0, \sigma^{2}$. Departure from homoscedasticity or normality will cause the estimators to be inconsistent (Wooldridge, 2002). In order to test the normality assumption, we estimate the Tobit model with polynomials (quadratic, cubic) of the fitted values as additional regressors. A Wald test is then performed to check whether these polynomials have jointly significant explanatory power. For all our models the null hypothesis of normality could not be rejected.

If the assumption of homoscedasticity is violated in Tobit models, regressions may result in inconsistent coefficient estimates. Consequently we also estimated heteroscedastic models where we model a heteroscedasticity term. The heteroscedasticity term includes the country dummies. When performing LR- tests on heteroscedasticity for all models, we notice that the null hypothesis (homoscedasticity) cannot be rejected in any of the models. When performing a Wald test on the joint significance of the variables in the heteroscedasticity term, the assumption of homoscedasticity is again satisfied.

As a robustness check we also estimated a generalized linear model (GLM) as proposed by Papke and Wooldridge (1996). More in particular, we estimated following specification:

$\mathrm{E}(\mathrm{Y} \mid \mathrm{x})=\mathrm{G}\left(\beta_{1}+\beta_{1} \mathrm{PA}+\beta_{2} \mathrm{FA}+\beta_{3} \mathrm{RC}+\beta_{4} \mathrm{PAxRC}+\beta_{5} \mathrm{FAxRC}+\beta_{6} \mathrm{SERVICES}+\beta_{7} \mathrm{AGE}+\beta_{8} \mathrm{TYPE}+\right.$ $\beta_{9}$ BUDGET $+\beta_{10}$ SIZE $+\beta_{10}$ COUNTRY).

whereby $G($.$) is specified as a logistic function, i.e. G(z)=\exp (z) /(1+\exp (z))$. Since this kind of regression leads to similar results as those of the Tobit analysis, they are omitted. ${ }^{8}$ However it proves that the results of the Tobit model are reliable.

\footnotetext{
${ }^{8}$ GLM estimates are available upon request from the author.
} 